\title{
Goods and Services Tax (GST): A Comprehensive and Uniform Indirect Tax Reform in India
}

\author{
Surbhi Gupta*
}

\begin{abstract}
Overcoming the loopholes in the existing indirect tax regime, Goods and services $\operatorname{tax}(G S T)$ is a major indirect tax reform in India. India is very close to its implementation, tentatively from 1 July 2017 as announced by Sri Arun Jaitely, the current Finance Minister. GST is a nationwide tax levied on supply of goods and services in India. It is a destination based value added tax levied at each stage in supply chain right from the manufacturer to the consumer with benefit of input tax credit at each stage thereby eliminating cascading effects. The final consumer thus will bear only the GST charged by the last dealer in the supply chain. The proposed GST regime is expected to bring a basket of benefits for the entire economy thereby favouring its implementation at the earliest by overcoming all the challenges. Proper planning, administration, timely guidance to the industry and training to both the tax officers and payers on GST will aid its smooth implementation.
\end{abstract}

Keywords: Goods and Services tax (GST); Central GST; State GST; Indirect taxation regime.

\subsection{Introduction}

GST has become one of the most hyped topics in India currently as India is very close to its implementation, tentatively from 1 July 2017 as announced by the current Finance Minister of India. In India, many reforms have been undertaken in the indirect taxation system over the years such as introduction of state VAT (based on input tax credit) replacing the cascading type sales tax system; CENVAT to provide input tax credit while paying excise duty on manufacture of goods; and taxation on supply of services at uniform rate.

*M.Phil Research Scholar, Department of Commerce, Delhi School of Economics, University of Delhi, Delhi. (email: surbhi08gpt@gmail.com) 
However, the existing indirect tax regime still needs improvement as it allows for multiplicity of taxes leading to complex tax structure, distortions, cascading effect and lack of tax compliance. Tax bases at both the central and levels are narrow, making the VAT chain incomplete with significant cascading elements, remaining at both the levels. The proposed GST regime is considered to be the next major comprehensive reform in the indirect taxation in India. It will subsume majority of central and state indirect taxes, putting an end to multiplicity of taxes. GST is a nationwide tax levied on supply of goods and services in India. It is a destination based value added tax levied at each stage in supply chain right from the manufacturer to the consumer with benefit of input tax credit at each stage thereby eliminating cascading effects. This paper intends to focus on understanding the concept of GST and its impact on the Indian economy.

GST in India was first introduced by P. Chidambaram(then Finance Minister) in his budget speech on $28^{\text {th }}$ February 2006 but its first deadline for implementation i.e. 1 April 2010 and successive deadlines could not be met because of political issues, need for constitutional amendments and building consensus of all the states on GST structure. After various negotiations between the central and state governments, BJP government was able to get consensus of all the states and the Constitution $\left(122^{\text {nd }}\right.$ Amendment $)$ Bill,2014 was passed by the Rajya Sabha on $3^{\text {rd }}$ August 2016 and by the Lok Sabha on $8^{\text {th }}$ August 2016 and was ratified by more than $50 \%$ of the state assemblies. Bill got the Presidential assent on $8^{\text {th }}$ September 2016 enabling the Bill to become a law. The GST Council has been established to decide on rates, exemptions, thresholds and other relevant legislations on GST.

\subsection{Research methodology}

This paper is based on exploratory research. It aims to gain familiarity and acquire new insights on GST in India. The research design employed for the study is descriptive in nature. Available secondary data was extensively used for the study. The required data on trends in indirect taxation in India has been obtained from Indian Public Finance Statistics. Different news articles, national and international journals and websites which focused on various aspects of GST were used for the study.

\subsection{Objectives of the study}

The following are the objectives of the study:

i) To examine the loopholes in the existing indirect tax regime in India and a need to move from the current indirect taxation regime to a more comprehensive and unified taxation regime i.e. Goods and Services Tax (GST); 
ii) To explore the reasons for deferment of GST in India and current situation of GST reform;

iii) To understand concept and key features of proposed GST regime;

iv) To understand the benefits GST brings for the economy and to critically analyse the impact of GST on various sectors of the Indian economy;

v) To identify the challenges that need to be resolved before implementing a flawless indirect tax regime in India and to offer suggestions to overcome those challenges.

We hope that all the relevant issues acting as roadblocks in GST's successful implementation are resolved expeditiously so that a flawless indirect taxation system is gifted to India. The paper is divided into seven sections. Section two reviews the existing literature and section three examines the existing indirect tax system in India and its loopholes. Section four explains the concept of GST and proposed benefits it will bring for the entire Indian economy. Section five proceeds to explore the roadblocks in GST's implementation so far. Section six looks at the proposed GST structure in India. Section seven analyses the implications of GST on various sectors of the Indian economy. Section eight seeks to identify the challenges/issues that need to be resolved before successful implementation of GST in India. Section nine concludes with some recommendations to overcome challenges in the implementation of GST.

\subsection{Literature Review}

Most of the research studies on GST suggest that if GST is implemented, it will rationalize the distorting and complex indirect tax regime prevalent in India and will act as a catalyst in the growth of the Indian economy. However the success of GST is contingent upon the flawless tax design and simplification of tax administration backed by sound information technology infrastructure.

Rao and Vaillancourt (1994) analysed the nature of inter-state disharmony in the Indian tax system and compared it with the tax disharmony in Australia, Canada and United States. Authors concluded that the degree of inter-state tax disharmony in India is substantially higher than that in Australia, Canada and United States. Origin based consumption taxes cause significant inter-state tax exportation with unfavourable effects on both equity and efficiency. Authors recommended that destination based taxes should replace the prevailing origin based taxes and Sales tax should be rationalised by broadening the base.

Purohit (2010) proposed a road map for administrative changes in the implementation of goods and services tax, keeping in mind taxpayer convenience and the need to have the least possible compliance cost. Author has suggested following 
measures for successful administration of GST: a) There should be thorough reengineering of the departments of GST at both the levels of government; b) Crossverification of documents must be strengthened under the new regime so that the dealers do not avoid payment of tax and claim undue credit for taxable sales; and c) There is a need for proper audit plan to cover different economic activities.

Vasanthagopal (2011) assessed the positive impacts of GST on the various development areas like manufacturing, MSME, GDP, government revenue etc. Author concluded that positive impact of GST on the various development areas are dependent on a neutral and rational design of GST, balancing the conflicting interest of various stakeholders and full political commitment.

Bhasin (2013) looked at the evolution of sales tax from the origin based central sales tax to value added tax(VAT) and to a proposed destination based GST. She concluded that the introduction of GST is expected to end the long standing distortions of differential treatment of manufacturing and service sector. Adequate preparation by resolving all the issues and concerns for the changeover rather than an arbitrary fixed schedule should be the sole criterion for deciding the time for introduction of GST. Mukherjee (2015) argued that reform in tax administration is as important as tax policy for mobilisation of revenues. Given the present state of diversities in tax administration across central and state governments, it is important that administrative reforms such as investment in manpower, infrastructure, research and training should take place soon to administer GST effectively.

\subsection{Indirect Tax Structure in India}

\subsection{Present structure of indirect taxation in India}

India has a federal form of government where the taxing powers with respect to both direct and indirect taxes have been divided among the governments at the central and the state levels under the constitution of India. India gets a substantial bulk of its revenue from indirect taxes. The ratio of indirect tax-GDP was $11.08 \%$ in 1980-81 and increased to $13.25 \%$ in $1989-90$. However it declined to $10.62 \%$ in $1999-2000$ but increased to $11.38 \%$ in $2015-16$ (Table 1). At the central government level, the percentage of indirect tax and direct tax in the total tax revenue was $55.91 \%$ and $44.08 \%$ respectively in 2014-15 showing the importance of indirect taxes at the union level (Indian Public Finance Statistics, 2015-16, Table No. 1.7 and 2.2). At the state government level, the percentage share of indirect taxes and direct taxes in the total tax revenue was $97.99 \%$ and $2.008 \%$ respectively in $2014-15$. This shows the importance of 
indirect taxes in the total state revenue (Indian Public Finance Statistics, 2015-16, Table

No. 3.2 and 1.7).

Table 1: TAX-GDP Ratios (Centre and state governments combined) 1950-51 to 2014-15(Selected Years)

\begin{tabular}{|l|c|c|c|}
\hline \multicolumn{1}{|c|}{ Year } & Direct tax (\%) & Indirect tax (\%) & Total (\%) \\
\hline $1950-51$ & 2.22 & 3.81 & 6.03 \\
\hline $1980-81$ & 2.18 & 11.08 & 13.26 \\
\hline $1989-90$ & 2.22 & 13.25 & 15.48 \\
\hline $1998-99$ & 2.72 & 10.20 & 12.92 \\
\hline $1999-2000$ & 3.02 & 10.62 & 13.65 \\
\hline $2007-08$ & 6.39 & 11.06 & 17.45 \\
\hline $2008-09$ & 5.83 & 10.43 & 16.26 \\
\hline $2009-10$ & 5.82 & 9.63 & 15.45 \\
\hline $2010-11$ & 5.79 & 10.55 & 16.34 \\
\hline $2011-12$ & 5.74 & 11.06 & 16.80 \\
\hline $2012-13$ & 5.71 & 11.53 & 17.25 \\
\hline $2013-14$ & 5.76 & 10.91 & 16.67 \\
\hline $2014-15(\mathrm{RE})$ & 5.66 & 10.92 & 16.58 \\
\hline $2015-16(\mathrm{BE})$ & 5.76 & 11.38 & 17.15 \\
\hline
\end{tabular}

Source: Indian Public Finance Statistics 2015-16, Table No. 1.8

Note: $R E=$ revised estimates, $B E=$ budget estimates

The Central Government, presently, levies the following major indirect taxes:

Excise duty: Introduced in 1944, excise duty (CENVAT) is levied in the form of a value added tax on excisable goods which are manufactured in India. Under CENVAT credit rules a manufacturer can avail credit of duty paid on-1) inputs 2) capital goods 3) input services used in or in relation to the manufacture of excisable goods. The general rate of excise duty is $12.5 \%$. It is the major contributor to the indirect tax revenue of the union government. Its share in the total indirect tax revenue was 33.48\% in 2014-15.

Central Sales tax (CST): Introduced in 1956, CST is levied by the central government on inter-state supply of goods but collected and retained by the state governments. It is an origin based tax. The general rate of CST is $2 \%$.

Service tax: Introduced in 1994, it is levied on the provision of services (except in the negative list) in India (except in the state of Jammu and Kashmir). Service tax is applied at a uniform rate of $15 \% . \%$. Its share in the total indirect tax revenue of the union was $30.47 \%$ in $2014-15$. 
Customs duties: Introduced in 1962, India's customs duty has the following components-

a) Basic custom duty

b) Additional customs duty (CVD) - goods imported into India are subject to levy of an additional duty equal to the excise duty levied on like articles if produced or manufactured in India.

c) Additional duty of custom (SAD)- levied to partially compensate for various domestic taxes like sales tax and other local taxes to provide a level playing field to indigenous goods which have to bear these taxes.

d) Education cess levied at 3\% on the basic custom duty and CVD. The total share of custom duties in the total indirect tax revenue of the union was $34.21 \%$ in 2014-15.

The State Government levies the following major indirect taxes:

Value added tax (VAT): Implemented in India from 1 April 2005, it is a tax levied on intra-state sale of goods. It replaced the earlier sales tax regime wherein the state governments collected the tax on intra- state supply of goods at one point from the transactions. The single point tax was collected either at the first or last stage with no input tax credit leading to cascading effect and tax evasion. VAT is a multi-stage tax collected at every point of sale with applicable set offs of input tax paid while purchasing the goods.VAT rates are:

1) $0 \%=$ zero rated

2) $1 \%=$ on gold and silver ornaments

3) $4-5.5 \%=$ lower rate on essential items

4) $12.5-15 \%=$ standard rate applicable on majority of goods

5) $20 \%=$ higher rate applicable on alcohol and motor fuels

It contributes majority of indirect tax revenue for the state governments. The share of sales tax in the total indirect tax revenue has risen steadily from $56.98 \%$ in $1990-91$ to $60.37 \%$ in $2000-01$ and to $65 \%$ in $2013-14$. This is the only important tax having a significant share in indirect tax revenue of the states.

State excise duty: It is levied on liquor and narcotic drugs. This is the $2^{\text {nd }}$ largest source of revenue collected by the state governments. Its share in indirect tax revenue of the states was $11.85 \%$ in $2014-15$

Octroi: Levied on entry of goods into a local area for consumption, use or sale. It is passed on to the municipal bodies.

Entry tax (not in lieu of octroi): It is levied on the entry of goods into a state.

Entertainment tax: It is levied on admission to places of amusement or entertainment such as cinema, circus, commercial shows or exhibition, etc. Its share in total indirect tax revenue has reduced from $1.45 \%$ in $1990-91$ to $0.36 \%$ in $2008-09$ and further to $0.27 \%$ in 2014-15. 


\subsection{Loopholes in the existing indirect tax regime in India}

State VAT at the state level and CENVAT at the central level is an improvement over the sales tax system and the excise duty system (without input tax credit) prevalent earlier. However the existing system still needs improvement because it allows for multiplicity of taxes leading to complex tax structure, cascading effect and lack of tax compliance. Tax bases at both the central and state levels are narrow, making the VAT chain incomplete with significant cascading elements remaining at both the levels.

Following are the main loopholes in the existing indirect tax regime:

a) VAT: State VAT is characterised by a narrow base, plethora of exemptions, multiple rate structure and cascading effect on account of break in the input credit chain. VAT regime is not uniform for all states. Provisions regarding credit on capital goods, exempt goods and VAT rates vary across states. States compete against each other on such grounds to attract capital and trade into their jurisdiction. This has created a divergence in the effective tax rates and enhanced the degree of tax disharmony (Rao and Vaillancourt, 1994).

Advantage of neutrality is confined only for purchases within a state, hence allocation of resources is driven by tax considerations. Also lack of availability of credit of central excise duty and service tax while paying VAT leads to cascading effect. So there must be integration of VAT on goods at the state level with tax on goods and services at the central level.

b) Central Sales Tax (CST): Availability of input tax credit on VAT is limited to intrastate purchases. CST paid on inter-state purchase of goods is not eligible for input tax credit causing cascading effect. CST is an origin based tax and acts as a stranded cost for inter-state importers. CST leads to tax exportation by rich states to poor states which are net importers of goods and services.(Rao and Vaillancourt,1994)

c) Central Excise Duty (CENVAT): Under the CENVAT, credit of tax paid on input of goods, services and capital goods is available in two installments over two years and not in one year which leads to cascading effect. Also large list of exemptions, high threshold( Rs. $1.5 \mathrm{cr}$ ) and lack of integration of CENVAT with state VAT hampers the input credit chain, causes cascading effect and widespread evasion (Rao,2009).

d) Service tax: Over the years, service tax has been expanded to cover new services, but still it is not comprehensive as a lot of services which can generate more revenues to the government remain uncovered. Also VAT payable on goods used as input in providing a service is not allowed as credit leading to cascading effect.

e) Entry tax: Entry tax rates vary across states and commodities and some states do not allow an input tax credit against the entry tax leading to cascading effect. 
f) Other problems: Poor tax administration leads to more disputes thereby leading to increased costs of compliances and undermined revenue collection. In case of transportation of goods, large amount of time is wasted in collection of taxes at state borders thereby leading to substantial delays. There also exists lack of cross verification with tax compliances.

Owing to the loopholes in the existing system a need was felt to introduce a more comprehensive and unified indirect tax regime in India by subsuming majority of central and state level indirect taxes.

\subsection{Goods and Services Tax (GST) and its Proposed Benefits for the Indian Economy}

\subsection{Meaning of GST}

Over the years, Value added tax (VAT) also recognised as goods and services tax (GST) in several countries, has become an important source of indirect taxation. So far more than 160 countries including European Union, Australia, Canada, Japan, New Zealand, Singapore, Brazil, etc. have already implemented GST in one form or the other. The concept of VAT in the world is more than half a century old. The concept was first conceived by the French Taxman Apparatchik Maurice Laure in 1954. The tax was designed as a 'consumption tax' such that the burden is borne by the final consumer. Since VAT can be levied on both goods and services it has also been termed as 'Goods and Services Tax' popularly known as 'GST'. It is a destination based tax levied at each stage in the supply chain on the supply of goods and services with the benefit of credit of tax paid by the dealer on the previous purchases.

The latest global corporate tax rate study made by KPMG international has found out that the Europe' $\mathrm{s}$ indirect taxes are the highest in the world. Goods and Services Tax (GST) or Value added Tax (VAT) rates in the countries of European Union average 19.5 percent, compared with 10.8 percent in Asia Pacific, 14.2 percent in Latin America and 17.7 percent in the OECD. The world's highest indirect taxes are found in Sweden (25\%), Norway (25\%) and Hungary (27\%). The lowest GST is charged in countries like Canada and Japan at 5\%, Malaysia at 6\%, Thailand and Singapore at $7 \%$. For a developing country like India which is getting more and more globalised, implementation of GST would ensure that India provides a tax regime that is almost similar to the rest of the world.

GST will be a nationwide tax levied on supply of goods and services in India. It will be a destination based, value added tax levied at each stage in supply chain right from the manufacturer to the consumer with benefit of input tax credit at each stage 
thereby eliminating cascading effects. GST will subsume majority of central and state indirect taxes, putting an end to the complex indirect tax regime and multiplicity of taxes.

Currently taxes treat goods and services differently. Good attract excise at the manufacturing level and VAT at the time of sale. In contrast, services attract only one levy i.e. service tax on provision of taxable services. This distinction in the GST regime would disappear as both goods and services would be treated at par for taxing purposes.

Key features of the Indian GST model have been discussed in section six of this paper.

\subsection{Proposed Benefits of GST for the Indian Economy}

a) Rationalisation of tax structure: GST will simplify the current indirect tax regime in India by subsuming majority of indirect taxes putting an end to multiplicity of taxes. Simplified structure, transparency, better administration, simplified procedures for payment of tax; filing of returns; registration, availability of input tax credit will encourage tax compliance and avoid tax evasion and distortions.

b) Common national market: GST will ensure that indirect tax rates and structures are common across the country thereby increasing certainty and ease of doing business. All this will make India a dynamic common market giving opportunities to trade with other states.

c) Boost to revenues: GST model will help to control leakage of tax from the system. Its Implementation is expected to generate more tax revenues for both central and state governments owing to wider tax base, lesser evasion and better conformity on account of a sound IT infrastructure and 'seamless' input tax credits.

d) End of cascading effect: Currently taxes are levied at multiple stages such as CENVAT, Central state tax, VAT, entry tax etc. leading to cascading effect. All these levies will be replaced by a single GST paid on supply of goods and services with a comprehensive and continuous chain of set off benefits up to the retail level thereby putting an end to the cascading effect.

e) Foster economic growth: Implementation of GST will lead to efficient allocation of resources, generation of employment, more consumption (due to lower prices) and improvement in exports. This will spur India's economic growth. According to NCAER Report (December, 2009) implementation of GST across goods and services is expected, ceteris paribus, to provide gains to India's GDP somewhere within the range of $0.9 \%$ to $1.7 \%$.

f) Boost to investments: GST is a tax on consumption and not on income, so it inherently encourages savings and investments (Bhasin, 2013). Also, presently, for many capital goods, input tax credit is not available. Full input tax credit under GST would mean drop 
in the cost of capital goods and hence will provide boost to investments. GST is expected to boost India's economic growth and improve ease of doing business which will bring in a sound holistic investor friendly environment in India. To exploit such a huge opportunity it is expected that foreign investors both FDIs and FPIs will come to India and foreign investment in India will increase.

g) Lower cost of logistics and inventory: Post GST implementation, companies could generate substantial savings in logistics and distribution costs as the need for multiple sales depots will be eliminated. Given the current complex tax structure, the logistics decisions and the choice of setting up of inventory as well as distribution centers are based on tax rates rather than operational efficiency. With GST these decisions will purely be based on operational efficiency and help setting up of warehouses at cheaper locations which will help in reaching customers faster and offering commodities at lower prices.

h) Push to 'Make in India' and export competitiveness: Manufactured goods will become more competitive and less costly as GST addresses cascading of taxes, inter-state tax, high logistics cost and fragmented markets. Exports will also be zero rated. This will make Indian goods and services more competitive in the international market and give boost to Indian exports. All this will give a push to Make in India initiative. According to NCAER Report (December,2009) gains in exports post GST implementation are expected to vary between $3.2 \%$ and $6.3 \%$.

i) Relief to consumers: Biggest advantage would be in terms of overall reduction in tax burden on goods which is currently estimated at $25-30 \%$. Presently final consumer bears the burden of tax being paid by the producer at every stage. However, now the scenario will be different because producer will be able to get input tax credit, passing on the benefit of lower cost to the consumer. Prices of automobiles, FMCG and other commodities are expected to come down which will benefit consumers.

\subsection{Evolution of GST in INDIA}

Initiatives to implement GST in India were rooted a decade ago when in the year 2000 Sri Atal Bihari Vajpayee (the then Prime Minister of India) first conceived the idea to introduce GST in India. In 2003, the Kelkar Task Force on indirect taxes suggested a comprehensive goods and services tax (GST) based on the VAT principle. Vivacious by the success of state level VAT and need for a perfect solution owing to the loopholes in the prevailing indirect taxation system, P.Chidambaram (the then Union Finance Minister) in his budget speech of 2006-07 introduced the concept of GST and announced the target date for its implementation to be 1 April 2010. However, on $26^{\text {th }}$ February 
2010 the finance minister Pranab Mukherjee postponed the GST rollout to April 2011 because centre and state governments could not agree on the architecture of GST. On $19^{\text {th }}$ December 2014, Arun Jaitley (current Finance Minister) introduced the Constitutional (122 $2^{\text {nd }}$ Amendment) Bill, 2014 in the Lok Sabha which was passed on $6^{\text {th }}$ May 2015. On $12^{\text {th }}$ May bill was taken up in the Rajya Sabha but opposition member repeatedly stalled the proceedings of the house. The first deadline and successive deadlines of 1 April 2011 and April 2012 for implementation of GST could not be met.

\subsection{Reasons for deferment of GST}

a) Need for Constitutional amendment: India has a federal form of government. Article 246 under the $7^{\text {th }}$ schedule of the constitution provides for clear division of powers in respect of taxation between centre and states. While the centre at present does not have the right to tax sales of goods except in case of inter-state sale of goods, the state cannot levy tax on services.So constitution had to be amended to give powers to both the centre and states in respect of GST, a single tax on goods and services. A lot of time was taken up in drafting a suitable constitutional amendment after discussing with the central and state government ministers.

b) Overcoming the fears of state governments and building their consensus: A Constitutional Amendment bill has to be passed by a special majority. The NDA government had the numbers in the Lok Sabha but lacked majority in the Rajya Sabha. It needed other parties on board to get it passed. Building a consensus was difficult and time consuming. Concerns were expressed by the state governments that GST regime will take away state's monopoly of deciding tax rates, disturb their fiscal sovereignty and affect the revenues. So centre agreed to provide compensation to states for 5 years on account of loss of revenues to states. State governments' concerns on GST are acceptable because of the importance of indirect taxes particularly sales tax in the state's own tax revenue. It has grown considerably in depth and coverage and forms the mainstay of states' tax revenue.

After various negotiations between the Central and state governments, BJP government was able to get consensus of the state governments on GST's structure. The Constitution (122 $2^{\text {nd }}$ Amendment) Bill, 2014, was passed by the Rajya Sabha on $3^{\text {rd }}$ August 2016 and by the Lok Sabha on $8^{\text {th }}$ August 2016 . The Bill was ratified by more than $50 \%$ of the sate assemblies and got Presidential assent. GST Council has been set up to work on the details of GST structure based on which GST law will be drafted. Central GST law will have to be passed by the Parliament and State GST laws by the respective state assemblies. It is expected that GST will be rolled out by 1 July 2017. Table 2 provides a detailed timeline of the evolution of GST. 
42 | VISION: Journal of Indian Taxation, Volume 3, Issue 2

TABLE 2: GST- A Detailed Timeline

\begin{tabular}{|l|l|l|}
\hline \multicolumn{1}{|c|}{ Date } & Year & \multicolumn{1}{c|}{ Event } \\
\hline & 2000 & $\begin{array}{l}\text { Sri Atal Bihari Vajpayee (then PM of India) first conceived the } \\
\text { idea to introduce GST in India. } \\
\text { An empowered committee was set up in the year 2000 by Sri Atal } \\
\text { Bihari Vajpayee,headed by Asim Kumar Dasgupta to streamline } \\
\text { the GST model to be adopted and to develop the required } \\
\text { infrastructure needed for its implementation. }\end{array}$ \\
\hline 28 February & 2006 & $\begin{array}{l}\text { P.Chidambaram(then finance minister of India),in his Budget } \\
\text { speech introduced the concept of GST. He announced the target } \\
\text { date for implementation of GST to be 1 APRIL 2010. }\end{array}$ \\
\hline 28 February & 2007 & $\begin{array}{l}\text { P.Chidambaram, set up an Empowered Committee Of State } \\
\text { Finance Ministers (EC) headed by Asim Kumar Dasgupta to work } \\
\text { with the central government to develop roadmap for the } \\
\text { implementation of GST. }\end{array}$ \\
\hline 29 December & 2009 & $\begin{array}{l}\text { 13 } \\
\text { GST. Finance Commission headed by Kelkar made suggestion on }\end{array}$ \\
\hline 10 November & 2009 & The EC submitted its First Discussion Paper on GST. \\
\hline 22 March & 2010 & $\begin{array}{l}\text { Pranab Mukherjee(the then FM) postponed the GST rollout to } \\
\text { APRIL,2011. }\end{array}$ \\
\hline 29 March & 2011 & $\begin{array}{l}\text { Constitution (115 Amendment) Bill, 2011, introduced in the Lok } \\
\text { Sabha to approve necessary amendments to enable levy of GST. }\end{array}$ \\
\hline 7 August & 2011 & $\begin{array}{l}\text { Bill referred to The Standing Committee on Finance headed by } \\
\text { Yashwant Sinha. }\end{array}$ \\
\hline 18 December & 2013 & $\begin{array}{l}\text { Standing Committee submitted report in the Parliament. However } \\
\text { Bill lapsed due to dissolution of 15 }\end{array}$ \\
\hline 14 MakSabha.
\end{tabular}




\begin{tabular}{|c|c|c|}
\hline 1 August & 2016 & $\begin{array}{l}\text { FM Arun Jaitley moved amendments to the bill on political } \\
\text { consensus. }\end{array}$ \\
\hline 3 August & 2016 & $\begin{array}{l}\text { The CONSTITUTION ( } 122^{\text {nd }} \text { AMMENDMENT) BILL, } 2014 \text { was } \\
\text { passed by the Rajya Sabha. }\end{array}$ \\
\hline \multirow[t]{2}{*}{8 August } & 2016 & $\begin{array}{l}\text { The CONSTITUTION(122 } 2^{\text {nd }} \text { AMMENDMENT)BILL,2014 was } \\
\text { passed by the Lok Sabha }\end{array}$ \\
\hline & & $\begin{array}{l}\text { Note- India has } 29 \text { states and } 2 \text { union territories with legislature, } \\
\text { so } 16 \text { states were required to rectify the bill before it could be sent } \\
\text { for presidential assent (as per clause (2) of article } 368 \text { of the } \\
\text { Constitution of India). }\end{array}$ \\
\hline 12 August & 2016 & Assam became the first state to ratify the bill. \\
\hline 16 August & 2016 & Bihar ratified the bill. \\
\hline 17 August & 2016 & Jharkhand ratified the bill. \\
\hline 1 September & 2016 & $\begin{array}{l}\text { Odisha became the } 16^{\text {th }} \text { state to ratify the bill (minimum } \\
\text { requirement of } 50 \% \text { states ratifying the bill met, so bill sent for } \\
\text { Presidential assent). }\end{array}$ \\
\hline 8 September & 2016 & $\begin{array}{l}\text { The legislation amending the constitution i.e. Constitution }\left(122^{\text {nd }}\right. \\
\text { Amendment)Bill,2014 to enable GST became law with President } \\
\text { Pranab Mukherjee giving his assent to the bill. }\end{array}$ \\
\hline 12 September & 2016 & $\begin{array}{l}\text { Union Cabinet approves the establishment of GST council which } \\
\text { will decide on rates, exemptions, thresholds and relevant } \\
\text { legislation by } 22^{\text {nd }} \text { November } 2016 \text {. }\end{array}$ \\
\hline 23 September & 2016 & $\begin{array}{l}\text { GST Council finalized the timetable to work out rates and } \\
\text { legislative agenda. }\end{array}$ \\
\hline 3-4 November & 2016 & $\begin{array}{l}\text { Agreement on } 4 \text {-slab structure- } 5 \%, 12 \%, 18 \%, 28 \% \text { and } 28 \% \\
\text { plus cess on tobacco and luxury goods. }\end{array}$ \\
\hline $\begin{array}{l}22-23 \\
\text { December }\end{array}$ & 2016 & $\begin{array}{l}\text { Draft C-GST and S-GST laws finalized and Compensation Law } \\
\text { okayed. }\end{array}$ \\
\hline 16 January & 2017 & Division of tax administration between states and centre finalized \\
\hline 18 February & 2017 & Draft Compensation Law approved \\
\hline 16 March & 2017 & $\begin{array}{l}\text { S-GST, UT-GST legislations cleared, highest GST rate capped at } \\
40 \%\end{array}$ \\
\hline 18-19 May & 2017 & ervices in rate slabs. \\
\hline
\end{tabular}




\subsection{Key Features of the Proposed GST Model in India}

- India will follow a dual GST model. It will have two components: one levied by the central government known as central GST (CGST) and other levied by the state governments known as state GST (SGST) to promote cooperative federalism.

- The CGST and the SGST would be levied simultaneously on every transaction of supply of goods and services except the exempted goods and services, goods which are outside the purview of GST, and the transactions which are below the prescribed threshold limits.

- Dual GST model would be implemented through multiple statutes: one for CGST and SGST/UGST statute for every state/union territory. The Central GST Act shall extend to whole of India including Jammu and Kashmir. Each State/union GST Act would extend to the relevant state/union territory.

- The single GST rate shall be split between central GST and state GST.

- Taxes paid against the central GST shall be allowed to be taken as input tax credit (ITC) for the central GST and could be utilized only against the payment of central GST. The same is applicable for the state GST. Cross utilization of ITC between the central GST and the state GST would not be allowed except in the case of inter state supply of goods and service under the GST model.

- IGST Model: The centre will levy and collect IGST on inter -state supply of goods and services, import/export of goods and services and supply of goods and services to or by special economic zone(SEZ) developer or a SEZ unit.

IGST $=$ CGST + SGST

The inter-state seller will pay IGST on value addition after adjusting available credit of IGST, CGST and SGST on his purchases. The tax collected would be divided between the centre and the states based on the recommendations of the GST council.

- GST is structured on destination principle. IGST will be levied on imports of goods and services into the country. Full set off will be available on the GST paid on imports of goods and services. Exports will be zero rated i.e. GST will not be applicable on exports from India but exporters will get credit of input tax paid on their earlier purchases. Similarly supply of goods and services to or by a SEZ developer or a SEZ unit will also be zero rated.

- GST Council: The Constitutional (122 ${ }^{\text {nd }}$ Amendment) Bill 2014 provides for the setting up of the GST council comprising of Union Finance Minister as the Chairperson and Finance Ministers of the respective states. GST council will decide revenue neutral rate, GST rates, threshold, exceptions, and other relevant 
legislations. It is the main decision making body that will finalize the design of GST. A decision shall be taken by $3 / 4^{\text {th }}$ majority with the centre having a $1 / 3^{\text {rd }}$ vote and the states the remaining $2 / 3^{\text {rd }}$ with the union finance minister having the veto power.

- GST will replace 17 indirect tax levies as follows:

\begin{tabular}{|c|c|c|}
\hline & Central Taxes & State Taxes \\
\hline & Central excise duty & 1) State VAT \\
\hline 2) & Additional excise duty & 2) Entertainment tax(other than the \\
\hline 3) & Excise duty levied & tax levied by local bodies) \\
\hline & Medical & 3) Central sales tax \\
\hline & Preparations(Excise Duties) Act & 4) Octroi \\
\hline & of 1955 & 5) entry tax(not in lieu of octroi) \\
\hline 4) & Service tax & 6) Purchase tax \\
\hline 5) & Additional customs duty & 7) Luxury tax \\
\hline & $\begin{array}{l}\text { Special additional duty of } \\
\text { custom }\end{array}$ & $\begin{array}{l}\text { 8) Taxes on lottery } \\
\text { 9) Taxes on Betting and gambling }\end{array}$ \\
\hline 7) & $\begin{array}{l}\text { Central surcharges and cesses } \\
\text { relating to the supply of goods } \\
\text { and services. }\end{array}$ & $\begin{array}{l}\text { 10) State cesses and surcharges as } \\
\text { they relate to the supply of goods } \\
\text { and services. }\end{array}$ \\
\hline
\end{tabular}

- Four rate structure: India will follow a four slab rate structure of GST as suggested by the GST Council in its meeting held on $3^{\text {rd }}$ November 2016. The proposed rate structure is as follows :

i) Lower rate of 5\%: on essential items

ii) Two Standard rates of $12 \%$ and $18 \%$ : on majority of goods and service

iii) Higher or sin rate of $28 \%$ : other consumer goods such as small cars

iv) $28 \%$ + cess: on tobacco, luxury cars, pan masala etc. Cess has been recommended to fund the compensation for revenue loss to states. (Refer Annexure Table A).

- Alcoholic liquor for human consumption has been kept outside the purview of GST. Initially GST on (i) petroleum crude (ii) high speed diesel (iii) petrol (iv) natural gas (v) aviation turbine fuel, shall not be levied. But the GST council will decide when GST would be levied on the same.

- Threshold: Businesses with an annual turnover of less than Rs.20 lakh will be exempted from GST. The threshold will be Rs.10 lakh in the north-eastern and hilly states (as decided by the GST Council on $23^{\text {rd }}$ September 2016 in a meeting with consensus). 
- Composition scheme: To reduce the administrative and compliance burden, small taxpayers having turnover of Rs.5o lakh or less in a financial year can opt for a composition scheme where the tax payer need to pay tax at the rate of $1 \%$ of turnover. But he can neither avail the benefit of input tax credit nor collect tax from the customer.

- Administration: As decided in the meeting of GST Council held on $16^{\text {th }}$ January 2017, State authorities will audit and scrutinize $90 \%$ of the assesses who have an annual turnover of Rs. 1.5 crore or less, while the centre will assess remaining $10 \%$. Those with turnover of over Rs. 1.5 crore will be equally divided between centre and state- $50 \%$ each. Each assesse will be assessed by only one tax authority. While the power to levy and collect IGST will lie with the centre but for its administration, by adding a special provision in law, states will also be cross-empowered in the same ratio.

- There shall be uniform procedures for collection of both central and state GST. The taxpayer would need to submit monthly returns in a common format along with an annual return electronically through GSTN portal or Facilitation Centers notified by the Board or Commissioner. Application for registration is to be made online either directly on GSTN Portal or through Facilitation Centers notified by the Board or Commissioner.

- GSTN: Goods and services tax network (GSTN) is a not for profit private limited company owned by the centre, states and non-government financial institution. It is tasked with providing the information technology infrastructure for the GST. GSTN portal will be a one stop destination for filing and processing of all taxes and is being designed by Infosys.

\subsection{Implications of GST on Various Sectors of the Indian Economy}

Since GST has not been implemented in India yet, it would be too early to precisely and accurately judge the impact of GST on various sectors and what it will bring for the entire economy. However, based on the information available in the public domain in the form of government reports, research papers, newspaper articles covering viewpoints of various stakeholders and economists, this paper attempts to analyse the likely implications of GST on various sectors of the Indian economy.

\subsection{E-commerce}

In India, e-commerce is growing rapidly and GST is supposed to benefit this sector the most. GST will enable e-commerce firms to optimise warehouse costs by optimising 
the number of warehouses depending on their business operations rather than setting up a warehouse only to optimize taxes. GST will provide e-commerce firms a single unified market, help in free movement of goods across the country and hence enable them to reach customers faster. The industry however has certain issues with the draft GST law. They are:

- The e- commerce operator will have to collect tax at source (TCS) from the payment made to the supplier. The operator would be required to make payment of such tax collected at source to Government and file periodical returns for the same. According to the Internet and Mobile Association of India (IAMAI), GST will raise operational costs and additional compliance burden for the e-commerce operators for e-commerce.

- Under the current regime online sellers have to register with every state they sell to. GST, is not expected to make it simple because as per draft GST law, every supplier has to register in state where a taxable supply of goods or services is made.

\subsection{Information technology}

India's major portions of IT revenues are from exports and same will continue to be zero-rated in GST which will be beneficial for the industry. However, according to R. Chandrashekhar( chief of NASSCOM), complex billing and invoicing requirements due to the supply and valuation provisions of the graft GST law, could complicate taxation for IT companies. Under the GST regime there are 3 taxation points namely CGST, SGST and IGST. Multiplying 3 GSTs with 37 jurisdiction (29 states and 7 Union territories) makes the total number of points of taxation to 111. Currently IT services are governed by a simple regime where there is one point of taxation i.e. the central service tax and single point of registration. So moving from single to 111 points of taxation would be a challenge in terms of ease of doing business. Multiple registrations in each state is also a source of complexity for IT companies.

\subsection{Aviation industry}

According to estimates by the top industry executives, India's aviation industry may have to bear an additional tax burden of up to Rs. 15000cr annually (currently the industry as to pay only about Rs.3600cr every year) once GST is implemented. Currently an airline needs to pay $6 \%$ service tax on economy class tickets and $9 \%$ service tax on business class a departure from the usual service tax rate of $15 \%$. No such abatement is likely to be available under the GST. Currently import of aircraft and aircraft parts are fully exempt from CVD and SAD, also there is no service tax or VAT on purchase of or lease of planes. Under the GST, CVD and SAD will be subsumed for all imports, so 
purchase or lease of aircraft parts will attract GST of $18 \%$. Also there would be an additional annual impact of lease rentals because Indian airlines lease many planes.

\subsection{Fast Moving Consumer Goods (FMGC)}

GST is expected to bring many benefits to the FMGC industry:

- Currently FMGC companies pay nearly $24-25 \%$ as tax including excise duty, VAT and entry tax. GST at $12 \%$ and $18 \%$ could yield in significant reduction in taxes.

- Reduction in logistics and distribution costs as need for multiple sales depot will be eliminated and there will also be rationalization of warehouses. However food companies may not get the benefit of concessional excise rates anymore.

\subsection{Small and medium enterprises}

Under GST regime, the exemption limit prescribed is that of Rs 10 lakh in north eastern states and Rs 20 lakh for rest of India. The limit is common for service industry, retail and manufacturing industry. Though there would not be any significant impact on service industry because gross margins are higher in service industry followed by retail business and manufacturing industry. But it would have deep rooted implications for retail business and manufacturing industry having small average net margins. They would be required to follow all procedural compliances regarding payment of taxes, returns, assessment, etc. The compliance cost and compliance burden would be huge for such small trader. Also many small companies are still not ready for GST and may not be able to comply with it even by next year. Many small companies that do not directly deal with big companies may have to handle the tax complexity and technology part all by themselves.

\subsection{Banking and financial services}

Inclusion of financial services in GST will lead to smooth and efficient disbursement of loans and allied services. However, the problem that needs to be resolved is that banking and financial companies will have to register all their branches in a state separately and treat them as a separate entity. It would make registering and then calculating GST in each transaction in every branch complicated. Also some services given by one branch in a state to another in a separate state may be taxed under GST. As a result compliance cost is set to go up. So the government may look at relaxing some rules in the GST framework that would make life little easier for banks, NBFCs and insurance companies such as single registration and centralized audit. 


\subsection{Challenges in the Implementation of GST}

\subsection{Administration}

One of the major challenges in implementing GST is regarding the administration of combined GST to avoid dual control because dealing with two separate tax administrations at central and state levels will add to the compliance costs for tax payers. Although the long battle of consensus on administration of dual GST model has been resolved in the meeting of GST Council held on $16^{\text {th }}$ January 2017, but it not clear whether the division of assesses between the centre and states is going to be on the basis of revenue or type of supply or some other basis. It would be interesting to see how this sharing of administration is going to be effected in practice because dual GST model has an inherent problem of administration.

\subsection{Multiple rate structure}

India will adopt a four slab rate structure of GST. India has justified multiple tax structure on the ground that it will address the problem of regressive nature of VAT and protect consumers as the tax rate on mass consumption items should be low for a country where large number of population is below the poverty line. One tax rate would lead to substantial price effect on specific products. Multiple tax structure would also ensure against revenue loss. However, multiple rates increase both administrative complexity and compliance costs and also create classification disputes. This is evident from current situation in India as various sectors whose goods/services have been fitted at the higher rate slab have started lobbying with the government for placing them at a lower rate. Decision regarding fitting of certain individual items into GST bands is yet to be taken and hope it would take into consideration the problems of multiple rates.

\subsection{Cascading effect}

Keeping petroleum products such as petrol, diesel, ATF, petroleum crude and natural gas outside the purview of GST will lead to cascading effect because petroleum products are widely used as inputs in most sectors. It will hamper export competitiveness of the domestic industries. At the state level, stamp duty, registration fees, electricity duty are not included in GST carrying cascading effect. Further entertainment tax levied by the local bodies will continue. Thus while the GST aims at unifying multiple taxes, it still leaves out some.

\subsection{IT infrastructure}

Although GSTN has been formed but the present status for development of IT platform is not clear. The effectiveness of the GST roll-out highly depends on how well and timely the IT infrastructure has been developed. 


\subsection{Number of statues}

Dual GST model would be implemented through multiple statutes, one for central GST and another state GST statue for every state.So more the number of statues more hurdles in the smooth implementation of GST. Harmonization of central and state GST laws particularly state laws is very essential especially with respect to laws on chargeability, taxable event, classification of goods and services etc. Otherwise GST will not be different from current VAT regime in India.

\subsection{Threshold for registration}

As per GST Council meeting held on $22-23^{\text {rd }}$ September 2016, businesses with an annual turnover of less than Rs.20 lakh will be exempted from the GST. The threshold will be Rs.10 lakh in the north-eastern and hilly states. Although lower threshold has been decided for less developed states to protect them from revenue loss but lower threshold in these states might lead to migration of investments by small scale industries to states having high thresholds in order to save taxes and avoid tax compliance.

\subsection{Compliance problem for small scale businesses}

Industry trackers point out that many companies especially the smaller ones are still not ready for GST and may not be able to comply with it even by next year. Many small companies that do not directly deal with big companies may have to handle the tax complexity and technology part all by themselves. In Malaysia which introduced GST in April, 2105, many businesses complained that the period of one and a half year provided by the government to get ready after GST laws were finalized was not sufficient. In order to avoid any kind of chaos among small businessmen in India, government should work hard to finalize GST laws at the earliest and give at least 6 months thereafter to the companies to be GST ready and hence implement GST by September 2017.

\subsection{Conclusion}

Goods and services tax is the most important reform in the indirect taxation in India which aims to overcome the loopholes in the existing indirect tax regime. It is expected to bring a basket of benefits for the Indian economy thereby favouring its implementation at the earliest. However the proposed benefits of GST are contingent upon the purity of the GST's design and the manner of its implementation. To fully exploit the benefits of GST, all the issues and challenges should be addressed expeditiously. 
The biggest challenge is the administration of dual GST model. Tax administration has a crucial role in ensuring the effectiveness of a tax policy. Administrative structure should be such that it does not undermine the administrative independence of the central and state governments' tax departments and yet should provide simplification and harmonization for taxpayers across the country to avoid dual control otherwise it will lead to failure of tax compliance. The software may be developed in such a way that all basic processes viz., filing of returns, registration etc. may be simple and standardized across the country.

There is a need for proper audit plan (to minimize the gap between the reported and actual statutory tax liability of the taxpayer) to cover different economic activities and large variety of taxpayers. Also cross-verification of documents must be strengthened under the new regime. Building consensus on GST Law (both Central and State GST Law) is a must. There should also be harmonization of State GST Laws so that the core idea of GST i.e. uniform nationwide tax on goods and services is retained. Switching over to the sophisticated tax system without preparation could prove counterproductive in terms of both revenue productivity as well as ease of implementation. So adequate training is necessary for both tax payers and tax enforcers. Officials of centre and state government should be trained on GST laws and IT systems. Sufficient time should be given to small sectors at least 6 months to be GST ready after GST laws and rules are finalized. Proper planning, preparation, timely readiness of flawless IT infrastructure and guidance to industry is fundamental of GST rollout and success. It has been a decade since the inception of the concept of GST in India but its implementation is still in progress. We hope for GST's speedy implementation by overcoming all the challenges. GST is the best example of cooperative federalism. All stakeholders must cooperate to introduce the flawless GST in India. Its timely implementation will take India to the new heights of progress.

\section{References}

Acharya, S. (2005). Thirty years of tax reform in India. Economic and Political Weekly, 40(20): 2061-2070.

Adhana, D.K. (2015). Goods and Services Tax (GST): A panacea for Indian economy. International Journal of Engineering and Management Research, 5(4): 332-338.

Bagchi, A. (2006). Towards GST: Choices and trade-offs. Economic and Political Weekly, 41(14): 1314-1317. 
52 | VISION: Journal of Indian Taxation, Volume 3, Issue 2

Bhasin, N. (2013). Indirect tax reforms in India: Towards national Goods and Services Tax. Journal of Commerce and Business Studies, 1(1): 25-33.

First Discussion Paper on Goods and Services Tax in India. (2009). Empowered Committee of State Finance Ministers, November 2009.

Goods and Services Tax (Compensation to the States for Loss of Revenue) Bill, 2016.

Indian Public Finance Statistics. (2015-2016).

Mansor, N.H.A. \& Ilias, A. (2013). GST: A new tax reform in Malaysia. International Journal of Economics Business and Management Studies, 2(1): 2-19.

Model GST Law, GST Council Secretariat, November 2016.

Model IGST Law, GST Council Secretariat, November 2016.

Moving to Goods and Services Tax in India: Impact on India's Growth and International Trade. (2009). National Council of Applied Economic Research (NCAER), December.

Mukherjee, S. (2015). Present state of Goods and Services Tax (GST) Reform in India. National Institute of Public Finance and Policy (NIPFP), Working Paper no. 6/2015.

Purohit, M. C. (2010). Issues in the introduction of Goods and Services Tax. Economic and Political Weekly, XLV (5): 12-15.

Rao, M. G. (2009). Feasibility of introducing GST in April 2010. Economic and Political Weekly, XLIV (29): 10-13.

Rao, M. G. (2009). Goods and Services Tax: Some progress towards clarity. Economic and Political Weekly, 44(51): 8-11.

Rao, M.G. \& Vaillancourt F. (1994). Inter-state tax disharmony in India: A comparative perspective. Publius, 24(4): 99-114.

Rao, R. K. (2010). Goods and Services Tax: The 13th Finance Commission and the way forward. Economic and Political Weekly, XLV (48): 71-77. 
Rao, R.K., \& Chakraborty, P. (2010). Goods and Services Tax in India: An Assessment of base. Economic and Political Weekly, 45(1): 49-54.

Report of the $14^{\text {th }}$ Finance Commission. (2015). Chapter-13. Goods and Services Tax. February 24.

Report of the Task Force on GST. (2009). $13^{\text {th }}$ Finance Commission, December 15.

Vasanthagopal, R. (2011). GST in India: A big leap in the indirect taxation system. International Journal of Trade, Economics and Finance, 2(2): 144-146.

\section{ANNEXURE}

Table A: GST Rates for Select Goods and Services

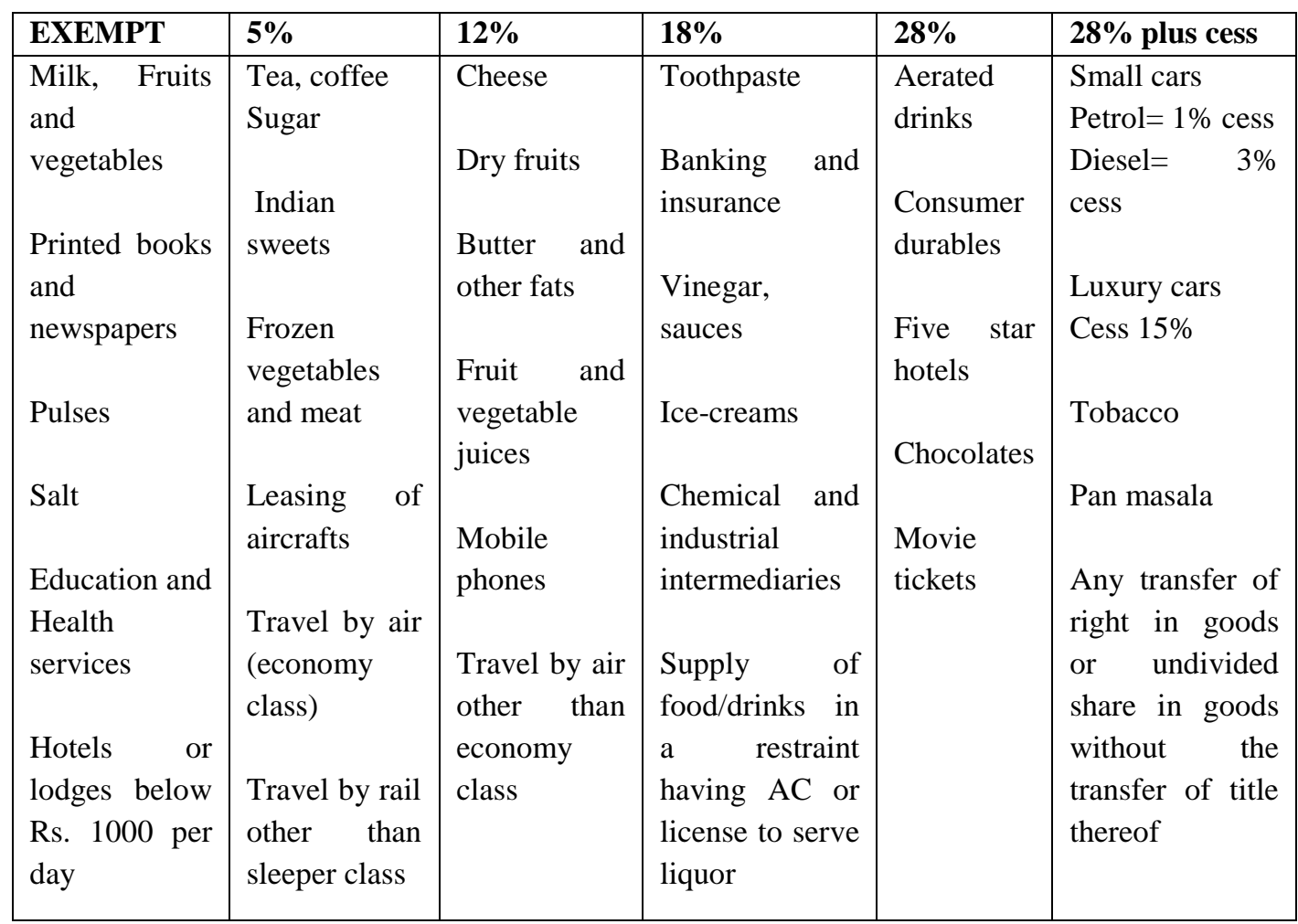

